\title{
O potrzebie alternatyw dla sądowego rozstrzygania sporów pomiędzy władzami administracyjnymi a podmiotami prywatnymi $w$ świetle Zalecenia Komitetu Rady Ministrów R (2001)9
}

\section{Wprowadzenie}

Działania administracji publicznej oparte na zasadach jednostronności, władczości i podporządkowania w nowoczesnych demokratycznych społeczeństwach stają się niewystarczające i mało skuteczne, a "zderzenie $\mathrm{z}$ zasady nienegocjująca, bardzo formalną $\mathrm{w}$ zachowaniach administracją publiczną staje się wyjątkowo bolesne"1.

Stąd propozycje modernizacji prawa administracyjnego. Reformy zmierzają w kierunku ograniczenia arbitralnych rozstrzygnięć na rzecz niewładczych form działania - porozumień między organami a obywatelami. Obecnie wskazuje się, że np. J. Łętowski wprost zwracał uwagę na potrzebę „dogadywania się" organu ze stroną postępowania administracyjnego ${ }^{2}$.

Postulaty dotyczące włączenia metod rozwiązywania sporów do prawa administracyjnego, a przede wszystkim w ramy procedury administracyjnej doczekały się realizacji. $W$ drodze nowelizacji przepisów

${ }^{1}$ I. Lipowicz, Istota administracji, w: Prawo administracyjne, pod red. Z. Cieślaka, I. Lipowicz, Z. Niewiadomskiego, G. Szpor, Warszawa 2013, s. 46.

2 J. Łętowski, Prawo administracyjne dla każdego, Warszawa 1995, s. 184-185; M. Sieniuć, Mediacja w postępowaniu administracyjnym, w: Prawo procesowe administracyjne, seria System Prawa Administracyjnego, pod red. R. Hausera, Z. Niewiadomskiego, A. Wróbla, t. 9, Warszawa 2017 s. 242. 
Kodeksu postępowania administracyjnego ${ }^{3} \mathrm{z}$ dniem 1 czerwca 2017 r. do k.p.a. wprowadzono mediację oraz znowelizowano przepisy o mediacji w postępowaniu sądowoadministracyjnym ${ }^{4}$.

Sygnalizowane zmiany dokonały się pod wpływem koncepcji alternatywnego rozwiązywania sporów. Idea alternatywnego rozwiązywania sporów zrodziła się w obrębie anglosaskiej myśli prawnej, stąd pojęcie to najczęściej oznacza się akronimem ADR, od angielskich słów alternative dispute resolution ${ }^{5}$. Punktem wyjścia dla zrozumienia koncepcji ADR jest ustalenie różnicy pomiędzy rozwiązaniem a rozstrzyganiem sporów. Rozwiązywaniem sporu nazywamy wszelkie niewładcze zachowania zmierzające do zakończenia sporu poprzez odnalezienie satysfakcjonującego obie strony rezultatu. Natomiast rozstrzyganie sporu to proces arbitralnego narzucania decyzji kończącej spór w stosunku do jednej lub obu stron sporu'.

Do metod rozwiązywania sporów zalicza się negocjacje, mediację i koncyliację oraz z pewnymi zastrzeżeniami arbitraż. Rozstrzyganie sporu następuje w trybie adjudykacyjnym, którego przykładem jest klasyczny proces sądowy. Metody rozwiązywania i rozstrzygania sporów można uznać za alternatywne ${ }^{7}$.

Koncepcja alternatywnego rozwiązywania sporów należy do węzłowych problemów sądownictwa. U jej podstaw legła bowiem krytyczna analiza kontrolowanego przez państwo wymiaru sprawiedliwości. Najczęściej formułowanymi zarzutami są: utrudniony dostęp do sądów, nadmierny formalizm, przewlekłość i wysokie koszty postępowania czy retrospektywny charakter rozstrzygnięć sądowych. Tak zrodziła się potrzeba znalezienia rozwiązań alternatywnych ${ }^{8}$.

${ }^{3}$ Ustawa z dnia 14 VI 1960 r. Kodeks postępowania administracyjnego (tekst jedn. Dz.U. 2017, poz. 1257 ze zm.), dalej „k.p.a.”.

${ }^{4}$ Ustawa z dnia 7 IV 2017 r. o zmianie ustawy - Kodeks postępowania administracyjnego oraz niektórych innych ustaw (Dz.U. 2017, poz. 935).

${ }^{5}$ Szerzej na ten temat zob. np. R. Morek, Alternatywne metody rozwiązywania sporów (ADR), w: Mediacje. Teoria i praktyka, pod red. E. Gmurzyńskiej, R. Morka, Warszawa 2018, s. 27; A.J. Mirończuk, Alternatywne a sądowe rozstrzyganie sporów cywilnych, Warszawa 2008, s. 24; E. Gmurzyńska, Mediacja w sprawach cywilnych w amerykańskim systemie prawnym zastosowanie w Europie i w Polsce, Warszawa 2007, s. 8-10. Por. również hasło „Alternative dispute resolution" w Oxford Dictionary of Law, ed. by E.A. Martin, J. Law, Oxford 2006, s. 28.

${ }^{6}$ Por. np. A. Korybski, Alternatywne rozwiązywanie sporów w USA, Lublin 1993, s. 31-32; A. Zienkiewicz, Studium mediacji. Od teorii ku praktyce, Warszawa 2007, s. 23.

${ }^{7}$ L. Morawski, Wstęp do prawoznawstwa, Torun 2015, s. 35; A. Korybski, op. cit., s. 104; A. Zienkiewicz, op. cit., s. 24.

${ }^{8}$ Szerzej na ten temat np. L. Morawski, Wstep..., s. 35-36; idem, Podstawy filozofii prawa, Toruń 2014, s. 285-286; E. Gmurzyńska, Mediacja w Stanach Zjednoczonych. Rola 
Początkowo alternatywne metody rozwiązywania sporów były jedynie pozasądowymi środkami rozwiązywania sporów. Jednak dość szybko zauważono, że np. mediacja może stanowić uzupełnienie klasycznego postępowania sądowego. Stąd pojawił się podział na pozasądowe alternatywy zewnętrzne oraz alternatywy wewnętrzne będące elementem postępowania sądowego'.

Dokumentem, w którym powyższe spostrzeżenia odniesiono do problemów sądownictwa administracyjnego, jest Zalecenie Komitetu Ministrów Rady Europy z dnia 5 września 2001 r. o alternatywach dla sądowego rozstrzygania sporów pomiędzy władzami administracyjnymi a podmiotami prywatnymi (on Alternatives to Litigation Between Administrative Authorities and Private Parties $)^{10}$. Wskazuje się, że przedmiotowe Zalecenie wyznacza europejskie standardy - rozumiane jako powszechny i ogólnie aprobowany wzorzec działania - ADR - w odniesieniu do prawa administracyjnego ${ }^{11}$.

Zalecenie dotyczące alternatywnego rozwiązywania sporów administracyjnych nawiązuje do wcześniejszych zaleceń wydawanych przez Radę Europy, w których podkreślano znaczenie różnych form ADR, a w szczególności mediacji, dla wymiaru sprawiedliwości ${ }^{12}$. Jest ono efektem pracy komitetu ekspertów Rady Europy nazwanego Grupą Roboczą ds. Prawa Administracyjnego (CJ-DA), działającego pod egidą Europejskiego Komitetu ds. Współpracy Prawnej (CDCJ). Problematyką alternatywnego rozwiązywania sporów pomiędzy administracją

prawników, w: Alternatywne metody rozwiazzywania sporów. Przegląd zagadnień, pod red. R. Świeżaka, M. Tańskiego, Warszawa 2003, s. 36; R. Morek, ADR - alternatywne metody rozwiązywania sporów w sprawach gospodarczych, Warszawa 2004, s. 7.

${ }^{9}$ L. Morawski, Podstawy..., s. 285.

${ }^{10}$ Dalej „Zalecenie nr R (2001)9” lub „Zalecenie”. Tekst Zalecenia i dokumentów towarzyszących znajduje się na stronie internetowej Rady Europy, https://wcd.coe.int (dostęp: 10 VIII 2018).

${ }^{11}$ Z. Kmieciak, Postępowanie administracyjne i sadowoadministracyjne a prawo europejskie, Warszawa 2010, s. 173.

${ }^{12} \mathrm{~W}$ preambule Zalecenia znajdziemy odwołanie do Zalecenia R (81)7 z dnia $14 \mathrm{~V}$ 1981 r. o środkach ułatwiających dostęp do wymiaru sprawiedliwości (Recommendation No. R (81)7 on measures facilitating access to justice) oraz Zalecenia R (86)12 z dnia 16 IX 1986 r. o środkach zapobiegających nadmiernemu obciążeniu sądów i ograniczających to obciążenie (Recommendation No. R (86)12 concerning measures to prevent and reduce the excessive workload in the courts), które zachęca do korzystania z przyjaznych metod rozwiązywania sporów zarówno poza sądem, jak również przed i w trakcie postępowania sądowego (the use of friendly settlement of disputes, either outside the judicial system altogether or before or during legal proceedings) - pkt 3-4 Zalecenia oraz Z. Kmieciak, op. cit., s. 173. 
publiczną a podmiotami prywatnymi Grupa Robocza ds. Prawa Administracyjnego zajęła się w $1999 \mathrm{r}^{13}$

W treści przedmiotowego aktu znajdują się wytyczne dotyczące wykorzystywania metod ADR do rozwiązywania sporów pomiędzy władzami administracyjnymi a podmiotami prywatnymi, które nazywa się tu sporami administracyjnymi (administrative dispute). Termin "spór administracyjny" przewidziano w preambule Zalecenia R (2001)9 oraz w wielu jednostkach redakcyjnych memorandum wyjaśniającego, stanowiącego załącznik do projektu Zalecenia (dalej "Memorandum")14.

Do środków mogących stanowić alternatywę dla sądowego rozstrzygania sporów administracyjnych w Zaleceniu zaliczono:

- wewnętrzną kontrolę aktów administracyjnych (internal review),

- postępowanie pojednawcze/koncyliację (conciliation),

- mediację (mediation),

- ugodę (negotiated settlement) oraz

- arbitraż (arbitration).

Poza tym w Memorandum opisano instytucję rzecznika (ombudsman), którego działalność również prowadzi do pozasądowego rozwiązania sporu $^{15}$.

Celem artykułu jest przedstawienie przyczyn, które przemawiały za potrzebą uchwalenia Zalecenia o alternatywach dla sądowego rozstrzygania sporów administracyjnych. Zreferowanie tego zagadnienia jest o tyle istotne, że Zalecenie to wywarło znaczący wpływ na polskie rozwiązania w zakresie wprowadzania metod rozwiązywania sporów do prawa administracyjnego. Przypomnienie motywacji Komitetu Ministrów Rady Europy jest w związku z tym wskazaniem argumentów, które powinny być brane pod uwagę $\mathrm{w}$ dyskusji nad zasadnością stosowania mediacji $\mathrm{w}$ polskim postępowaniu administracyjnym i sądowoadministracyjnym.

${ }^{13}$ Jak wskazuje się w memorandum wyjaśniającym do projektu Zalecenia, inspiracją dla podjęcia aktywności na polu wykorzystania ADR w administracji publicznej była konferencja zorganizowana przez Radę Europy i portugalskiego Ministra Sprawiedliwości pn. Alternatywne rozstrzyganie sporów sądowych pomiędzy władzami administracyjnymi a jednostkami prywatnymi: koncyliacja, mediacja, arbitraż, która odbyła się w Lizbonie w dniach 31 V - 2 VI 1999 r. Zob. pkt 9-10 memorandum wyjaśniającego do projektu Zalecenia R (2001)9.

${ }^{14}$ Na przykład pkt 6-9 Zalecenia oraz pkt 6, 30, 98, 101 Memorandum.

${ }^{15}$ Por. Sekcja I.1.i.ii Zalecenia. Na ten temat zob. również: A. Skóra, Nowe sposoby rozstrzygania sporów (litigation) między organami administracji publicznej a osobami prywatnymi w świetle rekomendacji Komitetu Ministrów Rady Europy nr R(2001)9 z dnia 5 września 2001 r., "Gdańskie Studia Prawnicze” 2005, t. 13, s. 301. 


\section{Przyczyny uchwalenia Zalecenia R (2001)9}

Metody rozwiązywania sporów wskazane w Zaleceniu R (2001)9 stanowią alternatywę dla postępowania sądowego, stąd uchwalenie tego aktu uzasadniano sytuacją sądowego wymiaru sprawiedliwości w państwach członkowskich Rady Europy. Analizując istniejące w tych państwach status quo w zakresie sądowego rozstrzygania sporów pomiędzy władzami administracyjnymi a stronami prywatnymi, dostrzeżono pewne generalne problemy.

Zaliczono do nich przede wszystkim wzrastająca, a nawet nadmierną liczbę spraw wpływających do sądów. Jednocześnie podkreślono, że sprawy te są coraz bardziej specyficzne, szczególne pod względem przedmiotowym i podmiotowym. Ten stan rzeczy prowadzi do, jak się wyrażono, przeciążenia sądów (overburdening of the courts). Problem ten odniesiono również do sądów rozstrzygających spory administracyjne $^{16}$.

Wskazując na kolejne problemy wymiaru sprawiedliwości, w Memorandum podniesiono, że w przypadku niektórych państw członkowskich Rady Europy sądy nie są przygotowane merytorycznie i proceduralnie do rozstrzygania sporów administracyjnych ${ }^{17}$.

Ponadto wśród przyczyn, dla których zdecydowano się uchwalić Zalecenie R (2001)9, wskazano na pewne cechy procedury sądowej in se, które powodują, że procedura ta nie zawsze najlepiej służy rozwiązywaniu sporów administracyjnych ${ }^{18}$. W ocenie autorów Zalecenia wzmiankowane cechy mogły być postrzegane jako wady publicznego wymiaru sprawiedliwości.

I tak stwierdzono, że co prawda sformalizowanie przewodu sądowego stanowi jedną z nieodłącznych gwarancji sprawiedliwego procesu, to jednak postępowanie przed sądem cechuje nadmierny formalizm, przez co procedura sądowa jest pozbawiona elastyczności (lackflexibility $)^{19}$. Rygory procesowe wykluczają elementy pojednawcze, eksponując kontradyktoryjność postępowania i jego sporny charakter. Jak to ujęto w Memorandum, wizyta w sądzie przypomina bitwę prawną (a legal battle). W szczególności dostrzegalne jest to $\mathrm{w}$ postępowaniu przed

${ }^{16}$ Por. np. pkt 5 i 6 Zalecenia oraz pkt 2, 3 i 15 Memorandum.

${ }^{17}$ W momencie uchwalania Zalecenia R (2001)9 w nie wszystkich krajach Rady Europy funkcjonowały sądy administracyjne - por. pkt 3 i 6 Memorandum.

${ }^{18}$ Pkt 6 Zalecenia.

${ }^{19}$ Pkt 7 Memorandum. 
sądem administracyjnym, w którym skarżący kwestionuje akt podjęty przez podmiot administracji publicznej ${ }^{20}$.

Restrykcyjne reguły postępowania, którego przedmiotem jest skarga na działanie lub bezczynność administracji publicznej, determinują $z$ kolei postawy stron $w$ procesie. Skargowa forma postępowania sprawia, że zarówno podmiot administracji publicznej, jak i skarżący zajmują jednoznacznie sprzeczne stanowiska. W Memorandum stwierdza się wręcz, że od momentu, w którym sprawa trafi do sądu, organ administracji publicznej nie chce przyznać się do popełnionego błędu ani przed sądem, ani przed skarżącym. Tymczasem od podmiotu administracji publicznej oczekuje się, aby był otwarty na modyfikacje swojego stanowiska, a nie zajmował twardej i niezmiennej pozycji ( $a$ hard and fast position) w zakresie ocen dotyczących legalności jego działań. Formalizm postępowania sprawia również, że nawet jeśli podmiot administracji, którego działania lub bezczynności dotyczy skarga, byłby skłonny do ustępstw, nie może tego uczynić, ponieważ stoją temu na przeszkodzie czynniki proceduralne. Dla przykładu wymienia się wśród nich terminy procesowe, rygory związane z wnoszeniem pism procesowych i skutki wniesionych pism $\mathrm{w}$ postępowaniu oraz zasady reprezentacji. Zbliżeniu stron nie sprzyjają również sformalizowane zasady komunikacji w przewodzie sądowym. Prezentacja stanowisk i wymiana informacji pomiędzy nimi ma najczęściej charakter pośredni - np. pisma adresowane są do sądu, a następnie przekazywane stronom - a funkcją tych czynności nie jest poszukiwanie kompromisu czy uzgadnianie stanowisk, ale "jedynie" możliwość zapoznania się z poglądami przeciwnika procesowego ${ }^{21}$.

W Memorandum niejednoznacznie natomiast oceniono jawny charakter rozprawy sądowej. Wskazano, że publiczne rozpatrzenie sprawy zapewniające uczciwe i sprawiedliwe postępowanie może bowiem niekiedy rozmijać się z potrzebami stron. W szczególności podmioty prowadzące działalność gospodarczą są zainteresowane dyskretnym załatwieniem kwestii spornej. Tymczasem w procesie sądowym odstępstwo od zasady jawności stanowi wyjątek, podczas gdy w prywatnym wymiarze sprawiedliwości (private justice) poufność jest jedną z zasad naczelnych ${ }^{22}$.

Komitet Ministrów zauważył również, że podstawowym celem postępowania sądowego jest rozstrzygnięcie sporu. Postępowanie przed

\footnotetext{
${ }^{20}$ Pkt 18 Memorandum.

${ }^{21}$ Pkt 19 Memorandum.

22 Pkt 29 Memorandum.
} 
sądem co do zasady kończy się wydaniem orzeczenia rozstrzygającego spór, a podczas ogłaszania wyroku silnie akcentuje się wskazanie strony wygranej i przegranej ${ }^{23}$. Ponadto, jak zauważył Komitet Ministrów, spór dotyczący faktów pomiędzy stronami (factual arguments) w sądzie poddany jest rygorom prawnym.

Odnosząc się do kwestii rozstrzygania sporów w kontekście działalności sądów administracyjnych, wskazano dodatkowo na supremację zasady legalizmu i pomijanie $\mathrm{w}$ procesie wyrokowania zasady słuszności ${ }^{24}$. Ponadto podkreślono, że dyskrecjonalność sędziowska w tych sądach jest bardzo ograniczona ${ }^{25}$.

Zgodnie ze stanowiskiem Komitetu Ministrów należy stwierdzić, że werdykt sądowy jest zatem efektem ścisłego przestrzegania przepisów prawa, skutkiem przeprowadzenia prostej i racjonalnej subsumcji, a mniej sformalizowane i mniej związane podejście do procesu i wyrokowania w sądownictwie państwowym, w tym w sądach administracyjnych, postrzegać należy jako sytuację wyjątkową ${ }^{26}$.

W związku z powyższym, ogólnie rzecz ujmując, Komitet Ministrów Rady Europy określił sądowy wymiar sprawiedliwości oraz procedury tam przestrzegane pojęciem machiny sądowej (the judicial machinery), która jawi się jako mechanizm sztywno określonych reguł.

${ }^{23}$ Pkt 20 Memorandum.

${ }^{24}$ Por. pkt 20 Memorandum. Te spostrzeżenia Komitetu Ministrów odpowiadają istocie krajowego sądowoadministracyjnego wymiaru sprawiedliwości. Istotą działań sądów administracyjnych jest kontrola działalności administracji publicznej z punktu widzenia legalności; w zakresie orzekania przyjęto przy tym model kasacyjny. Wyrok kończący postępowanie wyraża ocenę sądu co do zgodności z prawem działalności administracji publicznej - por. np. M. Jaśkowska, M. Masternak, E. Ochendowski, Postępowanie sądowoadministracyjne, Warszawa 2010, s. 211, B. Adamiak, J. Borkowski, Postepowanie administracyjne i sądowoadministracyjne, Warszawa 2013, s. 375; P. Wróbel, Sędzia w postępowaniu pierwszoinstancyjnym. Orzeczenia w pierwszej instancji, w: Metodyka pracy w sadach administracyjnych, pod red. R. Hausera, J. Drachala, Warszawa 2015, s. 527.

${ }^{25}$ Uwaga ta, chociaż odnosi się do krajowego sądownictwa administracyjnego, koresponduje z istotą wypowiedzi Komitetu Ministrów. Zob. Z. Czarnik, Prawotwórcza rola sądów a dyskrecjonalność sędziowska, w: Dyskrecjonalna władza sędziego. Zagadnienia teorii i praktyki, pod red. M. Dębińskiego, R. Pelewicza, T. Rakoczego, Tarnobrzeg 2012, s. 13. W tym samym zbiorze na ten temat również R. Sawuła, Uprawnienia dyskrecjonalne sędziego Wojewódzkiego Sąu Administracyjnego (ze szczególnym uwzględnieniem postępowania mediacyjnego i uproszczonego), s. 189-212. Na temat zagadnienia dyskrecjonalności sędziowskiej w sądach administracyjnych szerzej: D. Dąbek, Prawo sędziowskie w polskim prawie administracyjnym, Warszawa 2010, oraz K. Ziemski, M. Jędrzejczak, Dyskrecjonalność w prawie administracyjnym, Poznań 2015.

${ }^{26}$ Por. pkt 20 Memorandum. 
Przedmiotowe reguły nie sprzyjaja, bo i nie taka jest ich rola, zbliżaniu stanowisk stron i poszukiwaniu kompromisu, ale raczej pogłębiają antagonistyczną relację między nimi ${ }^{27}$.

Poza wymienionymi dotąd przyczynami odnoszącymi się do systemu wymiaru sprawiedliwości i procedur sądowych uchwalaniu Zalecenia R (2001)9 towarzyszyły także rozważania dotyczące społecznego postrzegania sądów i pełnionych przez nie funkcji. Punktem wyjścia dla refleksji na tym polu stała się obserwacja wskazująca na sukcesywnie wzrastającą świadomość prawną obywateli i innych podmiotów administrowanych. Zjawisko to $z$ jednej strony zostało rozpoznane jako podnoszący się stopień wiedzy na temat praw i roszczeń przysługujących podmiotom prywatnym. $Z$ drugiej natomiast strony chodziło o pogłębiające się poczucie braku możliwości pełnej i sprawiedliwej realizacji tych praw i roszczeń $w$ ramach procedury sądowej. W związku z tym w ocenie społecznej restrykcyjne przestrzeganie przepisów nie zawsze prowadzi do sprawiedliwych czy słusznych rozstrzygnięć. Nie chodzi przy tym o to, aby kwestionować zasady postępowania stanowiące gwarancje sprawiedliwego procesu, ale raczej o to, aby ich stosowanie nie stało na przeszkodzie sprawności działania sądu ${ }^{28}$.

Odwołując się do powyższych ustaleń, Komitet Ministrów podkreślił, że sytuacja zaistniała w sądowym wymiarze sprawiedliwości w zakresie rozstrzygania sporów administracyjnych może prowadzić do naruszenia praw stron postępowania sądowego, o których mowa w art. 6 ust. 1 Konwencji o Ochronie Praw Człowieka i Podstawowych Wolności z dnia 4 listopada $1950 \mathrm{r}^{29}$. Przedmiotowy przepis stanowi bowiem gwarancję "prawa do sądu” utożsamianego z „prawem do sprawiedliwego/

\footnotetext{
27 Por. pkt 19 Memorandum.
}

${ }^{28}$ Pkt 7, 21 i 22 Memorandum.

${ }^{29}$ Dz.U. 1993 Nr 61, poz. 284 (dalej EKPC). Por. pkt 5 Zalecenia. Zgodnie z art. 6 ust. 1 EKPC "każdy ma prawo do sprawiedliwego i publicznego rozpatrzenia jego sprawy w rozsądnym terminie przez niezawisły i bezstronny sąd ustanowiony ustawą przy rozstrzyganiu o jego prawach i obowiązkach o charakterze cywilnym albo o zasadności każdego oskarżenia w wytoczonej przeciwko niemu sprawie karnej". Wykładnia przepisu art. 6 ust. 1 EKPC dokonana przez Europejski Trybunał Prawa Człowieka pozwala obecnie stwierdzić, że poza sprawami cywilnymi i karnymi w zakresie przedmiotowym prawa do sądu mieszczą się również sprawy administracyjne. Zob. np. wyroki ETPC w sprawach: Ringeisen przeciwko Austrii z 16 VII 1971 r., skarga nr 2614/65; Baraona przeciwko Portugalii z 8 VII 1987 r., skarga nr 10092/82; Deumeland przeciwko Niemcom z 29 V 1986 r., skarga nr 9384/81; Lithgow i inni przeciwko Zjednoczonemu Królestwu z 8 VII 1986 r., skarga nr 9405/81; Georgiadis przeciwko Grecji z 29 V 1997 r., skarga nr 21522/93, loc. cit. § 34; Rolf Gustafson przeciwko Szwecji z 1 VII 1997 r., skarga nr 23196/94; J.S. i A.S. przeciwko Polsce 
uczciwego procesu sądowego" (right to a fair trial) lub "prawem do sprawiedliwego rozpatrzenia sprawy" (right to a fair hearing) ${ }^{30}$.

Tymczasem nadmiar spraw i specyfika sporów administracyjnych w ocenie Komitetu Ministrów stanowią zagrożenie dla prawidłowej realizacji prawa do sądu, a w sposób szczególny godzić mogą w gwarancję rozpatrzenia sprawy $w$ rozsądnym terminie ${ }^{31}$. W związku z tym, jako instrumenty wspierające wykonywanie prawa $z$ art. 6 ust. 1 EKPC, zarekomendowano środki alternatywne objęte Zaleceniem R (2001)9. Prawo do sądu należy bowiem rozumieć jako prawo dostępu do skutecznego środka prawnego umożliwiającego stronie sporu dochodzenie swoich praw ${ }^{32}$. Ze względu na szerokie pojęcie sądu ${ }^{33}$ prawo to można postrzegać jako prawo dostępu do procedury służącej rozwiązaniu sporu prowa-

z 24 V 2005 r., skarga nr 40732/98; oraz np. M. Miłosz, Bezczynność organu administracji publicznej w postępowaniu administracyjnym, Warszawa 2011, s. 321.

${ }^{30}$ Por. A. Pagiela, Zasada "fair trial" w orzecznictwie Europejskiego Trybunału Praw Człowieka, "Ruch Prawniczy, Ekonomiczny i Socjologiczny” 2003, z. 2, s. 125. Przywołany autor wskazuje (powołując się na: T. Braitsch, Gerichtssprache fuer Sprachunkundige im Lichte des "fair trial", „European University Studies” 1991, vol. 1091, s. 118), że „w anglosaskiej tradycji prawniczej zasada «fair hearing» oznacza podstawową gwarancję procesowa, od której pochodzą wszystkie inne” oraz że „Europejska Komisja Praw Człowieka uznała art. 6 za podstawową gwarancję prawa do «fair trial» np. w Sprawozdaniu Komisji nr 524/59 i 617/59", Yearbook of the European Convention on Human Rights, Yearbook 3, s. 322, 370.

${ }^{31}$ Por. pkt 5 Zalecenia i pkt 15 Memorandum oraz Z. Kmieciak, op. cit., s. 174.

${ }^{32}$ Por. wyrok Europejskiego Trybunału Praw Człowieka (ETPC) w sprawie Beles i inni przeciwko Republice Czeskiej z 12 XI 2002 r., skarga nr 47273/99, § 49, a także Wytyczne w zakresie stosowania artykułu 6. Prawo do rzetelnego procesu sądowego, wyd. Rada Europy i Europejski Trybunał Praw Człowieka 2013, s. 14.

${ }^{33}$ Pojęcie "sąd", którym posłużono się w treści art. 6 ust. 1 EKPC, odnosi się nie tylko do instytucji działającej w ramach krajowego wymiaru sprawiedliwości, ale może to być również podmiot funkcjonujący poza systemem sądowniczym, powołany dla rozstrzygnięcia konkretnego sporu lub ograniczonej liczby konkretnych kwestii, tak jak np. sąd arbitrażowy. Chodzi przede wszystkim o to, aby „sąd” był zdolny do właściwego orzekania z poszanowaniem gwarancji o charakterze prawnomaterialnym i procesowym (por. wyroki ETPC w sprawie: Campbell i Fell przeciwko Zjednoczonemu Królestwu z 28 VI 1984 r., skarga nr 7878/77, § 76; Lithgow i inni przeciwko Zjednoczonemu Królestwu z 8 VII 1986 r., skarga nr 9405/81, § 201; Rolf Gustafson przeciwko Szwecji z 1 VII 1997 r., skarga nr 23196/94 § 45). Instytucja mieszcząca się w granicach podmiotowych pojęcia "sąd" może przy tym pełnić i inne funkcje, np. administracyjne, regulacyjne, doradcze czy dyscyplinarne (por. wyrok ETPC w sprawie H. przeciwko Belgii z 30 XI 1987 r., skarga nr 8950/80, § 50. Na przykład w wyrokach ETPC w sprawach Sramek przeciwko Austrii z 22 X 1984 r., skarga nr 8790/79, § 36 oraz Aroyoru i inni przeciwko Grecji z 15 I 2009 r., skarga nr 10468/04, § 27, Trybunał uznawał, że status "sądu” w rozumieniu art. 6 ust. 1 EKPC posiadają odpowiednio regionalny Urząd do spraw obrotu nieruchomościami oraz Komitet do spraw rozstrzygania sporów w leśnictwie). 
dzonej w ramach instytucji respektującej gwarancje uczciwego procesu. W takim ujęciu pozasądowe środki rozwiązywania sporów mogą sprzyjać realizacji postanowień art. 6 ust. 1 EKPC.

Uchwalenie Zalecenia R (2001)9 zmierzało zatem do poprawy sytuacji w zakresie sądowego rozstrzygania sporów administracyjnych poprzez wprowadzanie pozasądowych środków rozwiązywania takich sporów do systemów prawa krajowego państw członkowskich Rady Europy. Jako wzór wskazano metody przyjęte $\mathrm{w}$ ramach procedury karnej czy w zakresie prawa rodzinnego ${ }^{34}$.

Środki rozwiązywania sporów regulowane Zaleceniem R (2001)9 w pierwszej kolejności miały stanowić alternatywę dla sądowego wymiaru sprawiedliwości, ale jednocześnie miały stać się środkiem zaradczym dla problemów sądownictwa publicznego. Stąd charakteryzując je, jako punkt odniesienia wskazano referowane wyżej wady procedury sądowej. Podczas gdy postępowanie sądowe cechuje nadmierny formalizm i brak elastyczności, metody alternatywne charakteryzują się niewielkim stopniem sformalizowania, a przez to znacznym stopniem elastyczności ${ }^{35}$.

Odformalizowanie i elastyczność są zatem źródłem zalet środków alternatywnych. Niewielkie wymogi formalne przy stosowaniu metod ADR wpływają bowiem na skrócenie terminu, w którym rozpatrywany jest spór administracyjny. To z kolei przyspiesza moment uzyskania rozwiązania mogącego stanowić zakończenie sprawy. W konsekwencji, co zostało już podniesione, środki alternatywne sprzyjają realizacji gwarancji rozpatrzenia sprawy $w$ rozsądnym terminie ${ }^{36}$.

Z szybkością postępowania koresponduje jego ekonomiczność. Korzystanie ze środków alternatywnych jest mniej kosztowne niż przeprowadzenie procesu sądowego, przy czym, jak zaznaczono, w pewnych przypadkach (np. arbitrażu pomiędzy państwem a globalną korporacją) koszty postępowań alternatywnych mogą być równie wysokie. To z kolei prowadzi do wniosku, że ukazane w Zaleceniu R (2001)9 korzyści płynące ze stosowania metod ADR będą ujawniać się w różnym stopniu w zależności od zastosowanego środka ${ }^{37}$.

Do stosowania środków alternatywnych miałoby skłaniać również i to, że postępowania prowadzone $\mathrm{w}$ ich formie oparte są na zasadzie poufności, która stanowi standard ADR i niekiedy bardziej odpowiada

\footnotetext{
${ }^{34}$ Pkt 4 Memorandum.

35 Por. pkt 8 Zalecenia.

${ }^{36}$ Por. pkt 17 Memorandum.

37 Por. pkt 17 Memorandum.
} 
potrzebom stron. W tym miejscu trzeba jednak zauważyć, że standard poufności wpisany w stosowanie środków alternatywnych pozostaje w kolizji z zasadą jawności działań administracji publicznej. Wydaje się, że w przypadku przedmiotowej kolizji zasad pierwszeństwo powinno zostać przyznane zasadzie jawności. Stosowanie środków alternatywnych do rozwiązywania sporów administracyjnych powinno zatem być odpowiednio dostosowane do zasad działania administracji publicznej ${ }^{38}$.

Rozwiązywanie sporów za pomocą środków alternatywnych daje również możliwość odwołania się do wiedzy ekspertów w danej dziedzinie $^{39}$. Specjalista dysponujący kierunkowym wykształceniem i praktyką zastępuje sędziego-prawnika, który w procesie wyrokowania odwołuje się do opinii biegłych. Stąd rozwiązanie niejednokrotnie szczególnie skomplikowanych na tle stanu faktycznego sporów administracyjnych $\mathrm{w}$ ramach procedur alternatywnych można powierzyć osobom dysponującym fachową wiedzą w tym zakresie. Opinie i stanowiska ekspertów stają się w danej sprawie sposobem rozwiązania sporu. Co warte podkreślenia, w takim przypadku rozwiązanie sporu oparte jest przede wszystkim na ustaleniach faktycznych ekspertów, a nie na ocenach prawnych sędziego. Można w związku z tym powiedzieć, że eksperci, kierując się wiedzą w danej dyscyplinie, rozwiązują spór, odwołując się do zasady słuszności, podczas gdy sędziowie, opierając się na prawie, rozstrzygają spór, odwołując się do zasady legalizmu.

Osobne miejsce poświęcono w Memorandum pojęciu słuszności (equity), którą można się kierować, rozwiązując spór administracyjny za pomocą środków alternatywnych. Jak przy tym zauważono, zasadę słuszności można przedstawiać w ujęciu szerokim i w ujęciu wąskim. W szerokim ujęciu odnosimy ją do sprawiedliwości, która oparta jest nie tylko na prawie, ale i na rozumie (based on reason) $)^{40}$. To, co sprawiedliwe, jest zatem zgodne z prawem oraz daje się pogodzić ze zdrowym rozsądkiem; norma prawna jest sprawiedliwa, gdy jest normą słuszną. W ujęciu węższym słuszność stanowi punkt odniesienia w procesie stosowania prawa, a odwołanie się do niej zapobiega jednoznacznie niesłusznym

${ }^{38}$ Por. pkt 29 Memorandum in fine, a także M. da Conceição Oliveira, Prace Komisji ds. Skuteczności Wymiaru Sprawiedliwości (CEPEJ) w zakresie mediacji. Opracowanie wytycznych służących usprawnieniu wdrażania Zalecenia Rec (2001)9 dotyczacego sporów między władzami administracyjnymi a osobami fizycznymi, w: Mediacja w sprawach administracyjnych, pod red. H. Machińskiej, Warszawa 2007, s. 27-28.

${ }^{39}$ Pkt 25 Memorandum oraz Z. Kmieciak, op. cit., s. 174.

${ }^{40}$ Pkt 27 Memorandum. 
skutkom czynności prawnych. Tak pojmowana słuszność stanowi więc środek korygowania indywidualnych aktów prawnych, ograniczając zakres stosowania przepisu, który narusza poczucie sprawiedliwości ${ }^{41}$. Może to mieć istotne znaczenie, gdyż do zasady słuszności odwołują się prawodawcy zarówno państw, w których obowiązuje system prawa stanowionego (civil law), jak również tych, w których istnieje system prawa precedensowego (common law $)^{42}$.

Zastosowanie środków alternatywnych powinno co do zasady prowadzić do słusznych rezultatów. Może to być jednak trudne do pogodzenia z zasadą legalności, której podporządkowana jest administracja publiczna. W związku z tym podkreślono, że podmioty administracji publicznej korzystające $z$ alternatywnych metod rozwiązywania sporów muszą respektować zasadę legalności i że korzystanie ze środków alternatywnych nie może prowadzić do naruszenia przedmiotowej zasady, obejścia prawa czy unikania obowiązków ${ }^{43}$.

Stąd zalecane przez Radę Europy środki alternatywne nie mogą wyłączać rozstrzygnięcia sprawy na drodze postępowania sądowego. Podmioty prywatne powinny mieć zatem zawsze zapewnioną możliwość objęcia porozumienia będącego rezultatem postępowań alternatywnych kontrolą sądową ${ }^{44}$. Kontrola sądu będzie bowiem gwarancją przestrzegania zasady legalizmu, ale także zasady słuszności, bezstronności i innych zasad uczciwego postępowania ${ }^{45}$.

${ }^{41}$ Zaprezentowane w Memorandum wąskie i szerokie ujęcie słuszności odpowiada podziałowi słuszności na słuszność indywidualna, samoistną oraz słuszność generalną, relacyjną. Szerzej na temat słuszności por. np. J. Stelmach, B. Brożek, Sztuka negocjacji prawniczych, Warszawa 2011, s. 43 i n.; W. Dziedziak, O prawie stusznym, Lublin 2015, s. 41 i n.; T. Widłak, Stuszność, w: Filozofia prawa, pod red. J. Zajadły, K. Zeidlera, Warszawa 2013, s. 331-335.

${ }^{42} \mathrm{~W}$ krajach systemu prawa stanowionego (civil law) słuszność stanowi integralny element wielu naczelnych zasad prawa, które znajdują się w konstytucji. Wzmiankowane zasady mogą być stosowane bezpośrednio na podstawie konstytucji lub być wdrażane za pośrednictwem aktów podkonstytucyjnych - przede wszystkim ustaw zwykłych. Natomiast w systemach common law zinstytucjonalizowana słuszność jest wykorzystywana w procesie stanowienia i stosowania prawa przez sądy. Słuszność bywa zatem ważnym kryterium wyrokowania w sądach państwowych. Jednak w przypadku środków alternatywnych stanowi ona zasadnicze kryterium oceny rozwiązań proponowanych dla sporu - por. pkt 28 Memorandum.

${ }^{43}$ Pkt 10 Zalecenia i pkt 30 Memorandum oraz Z. Kmieciak, op. cit., s. 174.

${ }^{44}$ Pkt 11 Zalecenia. Por. także D. Wiśniewska-Cazals, Mediacja w sprawach administracyjnych - standardy europejskie, w: Mediacja..., s. 16.

${ }^{45}$ Pkt 12 Zalecenia i pkt 30 i 31 Memorandum oraz Z. Kmieciak, op. cit., s. 175. 
Wskazując na zalety środków alternatywnych, uznano również, że pozasądowe procedury rozwiązywania sporów mają przyjazny charakter (friendly nature of the procedure $)^{46}$. Jak się wydaje, należy przez to rozumieć, że postępowanie sądowe ma mniej przyjazny charakter niż procedury ADR. Wniosek ten najprawdopodobniej oparto na założeniu, że środki alternatywne mogą bardziej odpowiadać oczekiwaniom społecznym w dziedzinie rozwiązywania sporów administracyjnych niż postępowanie przed sądem państwowym.

Finalnie stwierdzono, że stosowanie przyjaznych pozasądowych środków rozwiązywania sporów administracyjnych, o których mowa w Zaleceniu R (2001)9, i tym samym eliminacja antagonizmów w relacjach administracja publiczna - podmioty prywatne powinny doprowadzić do rezultatu, który w Memorandum określono jako zbliżenie administracji publicznej do społeczeństwa (bringing the administration closer to the public $)^{47}$.

\section{Zalecenie R (2001)9 i prawo do dobrej administracji}

Warto zauważyć, że już w drugiej połowie lat siedemdziesiątych ubiegłego wieku w ramach Grupy Roboczej ds. Prawa Administracyjnego rozpoczęły się działania zmierzające do wypracowania standardów dobrej administracji publicznej. Zwieńczeniem wieloletniego wysiłku w tej dziedzinie stało się uchwalenie Zalecenia R (2007)7 z dnia 20 czerwca 2007 r. w sprawie dobrej administracji (Recommendation $\mathrm{CM} / \operatorname{Rec}(2007) 7$ of the Committee of Ministers to member states on good administration). W części wstępnej Zalecenia R (2007)7 wskazuje się między innymi, że administracja publiczna, która zasługuje na miano "dobrej", poszukuje rozwiązań uwzględniających prawa i interesy podmiotów administrowanych, gwarantując im przy tym aktywny udział $\mathrm{w}$ procesie podejmowania decyzji administracyjnej. Dobra administracja kieruje się jednocześnie zasadami równości i bezstronności (equality, impartiality), a sprawy administracyjne załatwia w rozsądnym terminie (a reasonable time limit $)^{48}$.

${ }^{46}$ Pkt 17 Memorandum.

${ }^{47}$ Pkt 7 Zalecenia i pkt 16 Memorandum.

${ }^{48}$ Poza wymienionymi zasadami dobra administracja powinna respektować zasady praworządności, proporcjonalności, pewności prawa, poszanowania prywatności oraz jawności działań administracji. Szerzej na ten temat: Z. Kmieciak, op. cit., s. 67, a także 
Z powyższego wynika, że niektóre założenia i zasady, na jakich oparto działania dobrej administracji, korespondują z zasadami stanowiącymi istotę alternatywnego rozwiązywania sporów wyrażonymi w Zaleceniu R (2001)9. Uwzględniając chronologię przyjmowania zaleceń R (2001)9 i R (2007)7, można zatem postawić pytanie o to, czy Zalecenie R (2001)9 było jednym z aktów, które ukształtowały kryteria dla dobrej administracji.

Przede wszystkim zauważmy, że jakkolwiek Zalecenie R (2001)9 nie zostało wymienione wśród aktów, do których odwoływał się Komitet Ministrów, uchwalając Zalecenie o dobrej administracji ${ }^{49}$, to jednak ze względu na dostrzegalny w treści Zalecenia R (2007)7 postulat o niekonfliktowym charakterze działań administracji publicznej można dopatrywać się relacji pomiędzy tymi dwoma aktami Komitetu Ministrów. Relację tę można wyrazić poprzez tezę, że zasady stosowania środków alternatywnych nie stoją w sprzeczności z zasadami dobrej administracji. Co więcej, można wręcz powiedzieć, że spełnianie niektórych warunków, jakie Komitet Ministrów stawia dobrej administracji (np. gwarancje partycypacji społecznej czy procedowania w rozsądnym terminie), w sytuacji sporu mogą być realizowane poprzez wykorzystanie jednego ze środków alternatywnych. Oczywiście, należałoby w tym miejscu poczynić i takie zastrzeżenie, że dobrze wykonywana admini-

K. Puzio, Standardy europejskie wynikajace z prawa do dobrej administracji na gruncie postepowania administracyjnego i sądowoadministracyjnego, w: Skutki czynności procesowych w świetle standardów europejskich, pod red. D. Gila, Lublin 2014, s. 358.

${ }^{49}$ Przedmiotowe akty zostały wymienione w preambule Zalecenia R (2007)7. Wśród tych, które brano pod uwagę, zmierzając do instytucjonalizacji prawa do dobrej administracji na forum Rady Europy, wymienia się m.in.: Rezolucję (77)31 z dnia 28 IX 1977 r. o ochronie jednostki w związku z działaniami władz administracyjnych (Resolution (77)31 of the Committee of Ministers on the protection of the individual in relation to the acts of administrative authorities), Zalecenie R (80)2 z dnia 11 III 1980 r. w sprawie wykonywania uprawnień dyskrecjonalnych przez władze administracyjne (Recommendation No. R (80)2 of the Committee of Ministers concerning the exercise of discretionary powers by administrative authorities), wymieniane już Zalecenie R (87)16 z dnia 17 IX 1987 r. w sprawie procedur administracyjnych dotyczących dużych grup osób, Zalecenie R (2002)2 z dnia 21 II 2002 r. w sprawie dostępu do dokumentów urzędowych (Recommendation $\operatorname{Rec}(2002) 2$ of the Committee of Ministers on access to official documents), Zalecenie R (2003)16 z dnia 9 IX 2003 r. w sprawie wykonywania decyzji administracyjnych i sądowych w zakresie prawa administracyjnego (Recommendation Rec (2003)16 of the Committee of Ministers on the execution of administrative and judicial decisions in the field of administrative law) czy Zalecenie (2004)20 z dnia 15 XII 2004 r. w sprawie sądowej kontroli aktów administracyjnych (Recommendation Rec (2004)20 of the Committee of Ministers on judicial review of administrative acts). 
stracja, tj. administracja stosująca się do zasad wyrażonych w Zaleceniu R (2007)7, z założenia nie powinna stać się źródłem sporu. Innymi słowy, dobra administracja to administracja publiczna, która swoim działaniem nie generuje sytuacji spornych. Z tego punktu widzenia bardziej odpowiadające takiej administracji publicznej stałyby się środki zapobiegające powstawaniu sporów ${ }^{50}$. Niezależnie od etapu ich stosowania (w ramach prewencji czy już po ujawnieniu sporu) pozasądowe środki rozwiązywania sporów mogą służyć dobrej administracji przy wykonywaniu zadań publicznych.

Wobec powyższego istnieje związek pomiędzy dobrą administracją a alternatywnymi środkami rozwiązywania sporów. Środki te jako potencjalne formy działania administracji publicznej mogą ułatwić jej realizowanie oczekiwań, jakie Komitet Ministrów Rady Europy formułuje wobec administracji w Zaleceniu R (2007)7. Implementacja postanowień Zalecenia R (2001)9 do porządków prawnych państw członkowskich RE może być zatem postrzegana w szerszym kontekście i traktowana nie tylko jako sposób na wprowadzenie alternatyw dla systemu wymiaru sprawiedliwości, ale również jako droga do podniesienia sprawności działania administracji publicznej. Obydwa akty wyznaczają więc pewne standardy w zakresie zasad, na których powinny być oparte stosunki pomiędzy administracją publiczną a podmiotami prywatnymi ${ }^{51}$.

\section{Podsumowanie}

Postanowienia Zalecenia kształtowały polskie rozwiązania w zakresie wprowadzania alternatywnych metod rozwiązywania sporów do prawa administracyjnego. Dały one asumpt do wprowadzenia instytucji mediacji najpierw do postępowania sądowoadministracyjnego, a następnie postępowania administracyjnego.

Zakładając zaproponowany wcześniej podział na alternatywy wewnętrzne i zewnętrzne, należy przyjąć, że alternatywami zewnętrznymi są instytucje procesowe dostępne $\mathrm{w}$ ramach postępowania administracyjnego. W szczególności jest to wprowadzona w ostatnim czasie mediacja. Jednocześnie należy zauważyć, że mediacja stosowana w ramach postępowania sądowoadministracyjnego stanowi alternatywę

${ }^{50}$ Prewencyjnej funkcji środków alternatywnych poświęcono sporu uwagi w memorandum wyjaśniającym do projektu Zalecenia. Zob. pkt 50 i n. Memorandum.

${ }^{51}$ Por. D. Wiśniewska-Cazals, op. cit., s. 14. 
wewnętrzną. Ze względu zatem na możliwość prowadzenia mediacji zarówno w postępowaniu administracyjnym, jak i sądowoadministracyjnym można mówić o alternatywnym rozwiązywaniu kwestii spornych w układzie zewnętrznym (mediacja administracyjna) i wewnętrznym (mediacja sądowoadministracyjna).

Za odpowiadające metodom ADR wymienionym w Zaleceniu można też uznać występujące od dawna w postępowaniu administracyjnym instytucje ugody czy rozprawy administracyjnej, z tym jednak zastrzeżeniem, że służą one uzgadnianiu interesów stron postępowania i jako takie są metodami rozwiązywania tzw. sporów faktycznych ${ }^{52}$. W obecnym kształcie nie mogą więc bezpośrednio służyć rozwiązywaniu kwestii spornych z organem administracji publicznej.

Należy zauważyć, że zdiagnozowane w 2001 r. przez autorów Zalecenia problemy sądownictwa administracyjnego dotykają również krajowy wymiar sprawiedliwości. Mediacja nie jest jednak stosowana w postępowaniu sądowoadministracyjnym ${ }^{53}$. W związku z tym po kilkunastu latach obecności mediacji w Prawie o postępowaniu przed sądami administracyjnymi krytycy tej instytucji stwierdzają m.in., że nie ma ona żadnego znaczenia oraz wpływu na funkcjonowanie sądownictwa administracyjnego ${ }^{54}$. Należy jednak zauważyć, że nowelizacja przepisów dotyczących mediacji sądowoadministracyjnej, która nastąpiła z dniem 1 czerwca 2017 r., może przyczynić się do jej częstszego wykorzystywania i poprawienia bardzo niekorzystnej statystyki. Za szczególnie trafne uznaję powierzenie mediacji profesjonalnym mediatorom, a nie jak dotąd sędziom i referendarzom sądowym. Trzeba przy tym oczekiwać, że mediatorzy wyznaczani do mediowania w sprawach sądowoadministracyjnych będą umiejętnie łączyć doświadczenie mediacyjne z wiedzą na temat prawa administracyjnego. Uważam to za warunek sine qua non udanych mediacji sądowoadministracyjnych.

W przypadku mediacji administracyjnej brak jeszcze szczegółowych danych dotyczących jej stosowania. Pewne wnioski można jednak postawić na podstawie orzecznictwa sądów administracyjnych

${ }^{52}$ Na temat sporów faktycznych szerzej zob.: T. Woś, H. Knysiak-Sudyka, M. Romańska, Prawo o postępowaniu przed sadami administracyjnymi. Komentarz, Warszawa 2016 s. 437; iidem, Postępowanie sądowoadministracyjne, Warszawa 2017, s. 385.

${ }^{53} \mathrm{~W} 2017$ r. do postępowania mediacyjnego skierowano jedną sprawę - Informacja o działalności sądów administracyjnych w 2017 r., s. 19, http://www.nsa.gov.pl/sprawozdania-roczne.php (dostęp: 10 VIII 2018).

${ }^{54}$ Por. T. Woś, H. Knysiak-Sudyka, M. Romańska, Prawo o postępowaniu przed sądami administracyjnymi..., s. 692-694, 
w sprawach, w których rozstrzygano zarzut braku mediacji pomimo wniosku strony o jej przeprowadzenie. Po pierwsze, należy zauważyć, iż wpływ wniosków o mediacje wskazuje, że istnieje potrzeba mediowania kwestii spornych w postępowaniu administracyjnym. Odmowa przeprowadzenia mediacji przez organ prowadzący postępowanie nie jest jednak traktowana jako naruszenie przepisów prawa procesowego. Jak stwierdził Wojewódzki Sąd Administracyjny w Krakowie, ponieważ przeprowadzenie mediacji nie jest obowiązkowe, nie można zarzucić organowi naruszenia prawa ${ }^{55}$. Zaprezentowana teza wydaje się dyskusyjna ze względu na to, że polubowne rozwiązywanie kwestii spornych w drodze mediacji jest zasadą ogólną postępowania administracyjnego sformułowaną $w$ art. 13 k.p.a. Nie podejmując się formułowania $w$ tym miejscu glos krytycznych do przedmiotowego orzeczenia, można jednak stwierdzić, że na obecnym etapie mediacja administracyjna jest alternatywą dla sądowego rozstrzygania kwestii spornych ujawnionych $\mathrm{w}$ postępowaniu administracyjnym. Jednak aby nie podzieliła losu mediacji sądowoadministracyjnej, potrzeba nie tylko zaangażowania stron postępowania administracyjnego, ale również organów prowadzących te postępowania oraz być może nieco bardziej restrykcyjnego postrzegania zasady wyrażonej w art. 13 k.p.a. przez sądy administracyjne.

\section{ON THE ALTERNATIVES TO LITIGATION \\ BETWEEN ADMINISTRATIVE AUTHORITIES AND PRIVATE PARTIES ACCORDING TO THE RECOMMENDATION OF THE COMMITTEE OF THE COUNCIL OF MINISTERS R (2001)9}

\section{S u m mary}

The aim of the article is to explain the reasons for the introduction of mediation in administrative law. Mediation is presented in the light of the Recommendation of the Committee of the Council of Ministers R (2001)9 of 5 September 2001 on Alternatives to Litigation Between Administrative Authorities and Private Parties. The adoption of this act was justified by the situation of administrative courts in the member states of the Council of Europe. The common problems in the area of justice were the excessive number of court cases, excessive formalisation of court proceedings and a dispute resolution model that would disregard solutions that could satisfy both parties to the administrative dispute. It was also stated that these problems might have a negative impact on citizens' access to justice and lead to

${ }^{55}$ Wyrok Wojewódzkiego Sądu Administracyjnego w Krakowie z 26 IV 2018 r., sygn. II SA/Kr 323/18, CBOSA. 
the violation of the rights of the parties to court proceedings, referred to in Article 6 par. 1 of the Convention for the Protection of Human Rights and Fundamental Freedoms. The measures that may constitute an alternative to the judicial resolution of administrative disputes in the Recommendation include: internal control of administrative acts, amicable proceedings/conciliation, mediation, settlement and arbitration.

This Recommendation has shaped the Polish solutions in the field of introducing alternative dispute resolution methods to administrative law. However, in the realities of the Polish legal conditions included in the Recommendation, the proposals have become an incentive to introduce only the institution of mediation. First, it became part of the court-administrative proceedings, and then it was introduced to the administrative proceedings. Currently, when after the introduction of mediation to the Code of Administrative Procedure, the use of ADR methods under administrative law has again become the subject of a broader interest in the doctrine, it is worth recalling the reasons why in 2001 the Council of Europe recommended introducing alternatives to national legal orders.

Keywords: administrative law - alternative dispute resolution - administrative courts - mediation 